\title{
Some remarks on plant art ${ }^{\dagger}$
}

\section{Anna Zeidler-Janiszewska}

\begin{abstract}
The author analyzes artistic practices associated with the natural world, "from land art to garden art". In an overview of historical currents in art (since the 1960s), plant art is highlighted as an instrument of critique of land art, and a self-standing current which, among other things, addresses social issues and ecological threats. The author also analyzes specific examples of garden-related artistic practices within the cityscape, considering the criteria under which certain projects can be seen as successful (models to emulate). The text concludes with open-ended questions about the place of plant art in present-day critical discourses, i.e. with respect to landscape architecture, bioart, and technonature.
\end{abstract}

Key words

Art, aesthetics, environment, nature

I am interested in a certain trend noticeable in art practices involving components of the natural world: plants, animals, and minerals and the manner in which they are tackled by critics, theorists, and researchers of contemporary art.

For the majority of artists and a number of art critics, "land art," the American current of the late 1960s (shown for the first time in German galleries in 1969), provided both a positive and a negative frame of reference. The very fact that it addressed our relationships with nature was the positive element, whereas the fashion in which the issue was manifested became a negative reference point for later artistic practices.

What were the shortcomings of land art, which had already been alleged in the 1970 s when it was juxtaposed with "plant art"-the art of the garden and planting with all its connotations? First, it exhibited excessively spectacular grandeur which required substantial financing; second, few viewers were to see those works; third, land art drew on wild nature, on the archetypal vision of relationships with nature, while any discussion about the pieces focused in fact on the material which

$\dagger$ This is a transcription of the talk held by the author at the conference Miastonatura. Zielona przyszłość miast? [Citynature. The Green Future of Cities?] held at the Warsaw Academy of Fine Aarts on April 21, 2017; transcription prepared by Magdalena Gimbut and edited by Monika Weychert-Waluszko. 
documented it. Most of the land art oeuvre was interpreted in the categories of the sublime, just as Edmund Burke construed it: in opposition to beauty. Wild nature was supposed to afford sublime feelings, which did not necessarily apply to the documents to which viewers had access. In another, romantic approach, beauty was in a sense equated with nature. Two journals published in English propagated the current: Artforum and, to a lesser degree, October. A conceptualization advanced by the American critic Rosalind Krauss contended that works of earth art problematize the notion of landscape through sculpture in the expanded field of art. Theoretical reflection also took advantage of the category of the picturesque and, at times, beauty in the romantic understanding (e.g., in Christo's work). At any rate, the discourse revolved around those aesthetic categories.

Simultaneously, the practice was parodied in a variety of ways, and restricting audience access was immediately criticized as well. Then, with the plant art trend already developed, some of the more modest artistic projects carried out when land art was at its peak (i.e., the 1970s and the 1980s) began to be reconstructed. The reconstructions preferred to draw on artists from the fringe, who did not treat nature as a sinister creative force which compelled answers to fundamental questions of existence and metaphysics but rather as something under threat-something that requires our solicitude, an almost defenseless entity in fact. The aesthetic categories changed as well. Critics associated with that "modest" current emphasized that it is not about beauty, sublimity, or a combination of both, but rather a pursuit of other values that do not necessarily belong to the aesthetic-artistic realm. While the first current developed in the United States and Great Britain, the latter became widespread in countries such as the Netherlands or Germany, being conceptualized in, for instance, Kunstforum (1999a, 1999b). Two issues of the periodical, published under the joint theme of "the artist as a gardener," were exclusively dedicated to the matter. Besides incisive critique of land art, they offered more: the second volume contained an anthology of garden projects with various examples showing a new direction of action, resting on premises relating to LTGs (limits to growth), ecological threats, etc. Although certain continuity may be seen between the discourses of earth art and those of garden art, they involve thoroughly distinct forms of action. The aforementioned issue of Kunstforum provides very detailed analyses of plant art works which were found to have been exceptionally successful.

What examples are these?

One of them is Jenny Holzer's Black Garden (1994, Nordhorn, Germany). The artist worked at a dilapidated memorial to the fallen in the Franco-Prussian War, and subsequently soldiers killed in the two world wars, which represented an unwanted area of little concern. Following a commission from the municipal authorities and consultations with the inhabitants (the records may be found at the site, and have been provided to some extent in relevant articles), it was changed into a unique 
garden, as most of the plants there had a blackish hue or bloomed black. Black tulip bulbs were ordered from the Netherlands, though it needs to be noted that tulips-growers will know-change color over time, so every three or four years new ones had to be planted in order to maintain the original tone. Various other plants, almost all of them black, were ordered as well, including an apple tree from California which bears black fruit. The tree is situated in the center, being a kind of tree of the knowledge of good and evil. Besides complex horticultural arrangements, the benches placed in the garden were an important element in the project as well. They are just like the benches at the Centre for Contemporary Art in Warsaw, which Jenny Holzer left there having completed her Warsaw project and which she places in many other locations. The features are crafted from local stone and bear anti-war inscriptions in English and German. In any case, apart from the garden complex which occupies a fair amount of space in the center of the town, other research paradigms also come into play. Black Garden is an interesting object for those who study forms of commemoration; it is featured in books concerned with the anti-monument genre and offers a functioning example of collaborative art, because local inhabitants have to take care of it, preserve its colors, etc. This is one of the more extensively discussed examples of garden art.

Another example is the project entitled Flood, the work of the American Haha collective (1992-1995). As part of the Culture in Action festival in Chicago, the group designed a garden within a building-a hydroponic one-which was a rare feat in the 199os. Apparently, only one horticultural company in the entire United States offered trainings teaching people how to establish and tend to such a garden while also supplying the necessary equipment. Showing how such a garden worksrelying on water without even a grain of soil-was only one among many other goals. The garden was cultivated collectively as, next to artists, the locals became actively involved in vegetable growing. Another significant element was the fact that those suffering from AIDS could not eat plants grown in soil, as in their case the transfer of compounds from the latter into their food proved potentially harmful. Thus, the superior objective was to familiarize people with the disease and to provide a constant supply of vegetables to affected persons in the neighborhood and beyond. Furthermore, those involved had to learn how to work in such a garden. There were many volunteers, and later every borough in Chicago was said to have a hydroponic garden. At the same time, it was a venue for talks, discussions, a library of resources, etc. Consequently, just as in the previous case, the garden became a center of many activities and discourses.

Mark Dion's vivaria also supply an example of plant art, such as the Neukom Vivarium (2006) in the Olympic Sculpture Park in Seattle: an old decomposing tree, plus bacteria, plus adequate temperature, plus resources which describe processes of decay in nature. Vivarium chiefly serves educational purposes, being a visually attractive structure at the same time. Further example may be found in Park 
Fiktion in St. Pauli, a quarter of Hamburg, which became widely known thanks to, among others, documenta in Kassel. ${ }^{1}$ This is also a reclaimed area, revitalized through the efforts of the inhabitants. One could say that it represents an anti-gentrification project-a continually re-established community composed of immigrants and the underprivileged of Hamburg. Park Fiktion endures, people become involved in its cultivation and the events taking place there, as well as their documentation and education. Just as the previous gardens, this one is also mentioned in tourist guides.

I would argue that projects which win fairly broad recognition, are considered exceptionally successful, and continue to exist, always accomplish a range of additional goals. Thus, in order to obtain a complete picture of Black Garden in Nordhorn one must use the language of botany and act as a practitioner of botany and gardening, while at the same time employing terms related to art in public space and forms of commemoration-that is, one must apply notions from the domain of memory studies as well as those associated with collaborative art. In fact, I have not found a single instance, especially in the second issue of the Kunstforum compilation, which pertains solely to the cultivation of nature.

A theoretical account of these interwoven tendencies is provided by Brigitte Franzen, author of The Fourth Nature: Gardens in Contemporary Art (2000), who analyzes numerous examples demonstrating how various discourses overlap. She poses questions that remain unanswered, and I hope to some degree that she leaves them open-ended: what actually distinguishes such garden art from landscape architecture? Another query is how Ken Goldberg's and Joseph Santarromana's Telegarden (1995-2004) should be classified in terms of plant art? In this now defunct project, users were given special access to an actual garden in that they could remotely (online) control a robot to plant plants, water them daily, and even prune them. People from around the world participated in the garden by visiting a website and logging in; a plant could be planted after 100 clicks or so (every user was afterwards entitled to three plants only). A forum of exchange and discussion was available as well. Theorists stated that the garden gathered a transnational community. The project itself may be seen as an outcome of combining technology, nature, and culture; hence, it may be understood in terms of technonature, a notion that had already begun to function at the time. The question is whether such an undertaking belongs to a distinct current, perhaps bioart, or whether it may be classified as gardening in the first, broader sense-namely, as plant art. All these questions remain to be answered.

1 See http://park-fiction.net/. 


\section{References:}

Franzen, Brigitte. 2000. Die vierte Natur. Gärten in der zeitgenössischen Kunst. Köln: Verlag der Buchhandlung Walther König.

Kunstforum. 1999a. "KünstleralsGärtner." May/June.

Kunstforum. 1999b. "Das Gartenarchiv." July/August. 